\title{
Police launch criminal investigation into actions of emergency department
}

Published at www.cmaj.ca on Nov. 5

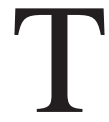

he Winnipeg Police Service has launched a criminal investigation into the 2008 death of Brian Sinclair, a homeless aboriginal man who went untreated for 34 hours in the waiting area of a downtown emergency room in Manitoba before succumbing to a simple bladder infection that spread to his bloodstream.

The police, who reviewed the Sinclair death earlier this year, confirmed that they are assembling a special team to conduct a full criminal investigation. No further details were released explaining why the police service waited to launch a full investigation and who or what exactly is being investigated.

The death of Sinclair, a doubleamputee with a long history of medical problems and a frequent visitor to the Winnipeg Health Sciences Centre emergency department, captured national attention and sent shock waves through the Manitoba medical community. A coroner's inquest has been called but a date has not yet been set.

Both the Manitoba government and the Winnipeg Regional Health Authority admitted grievous errors in judgment were committed when Sinclair first entered the emergency department in September, 2008. Both have pledged to cooperate with the police investigation, although the health authority noted in a written statement that two previous reviews of the Sinclair case found "no one person was individually responsible. We believe the police investigation will reach the same conclusion."

Despite those admissions, the Sinclair case has sparked a firestorm of criticism, in large part because of concerns the province and health authority withheld critical information about the events leading up to Sinclair's death. It also prompted the Sinclair family to file civil suits against the province and regional health authority.

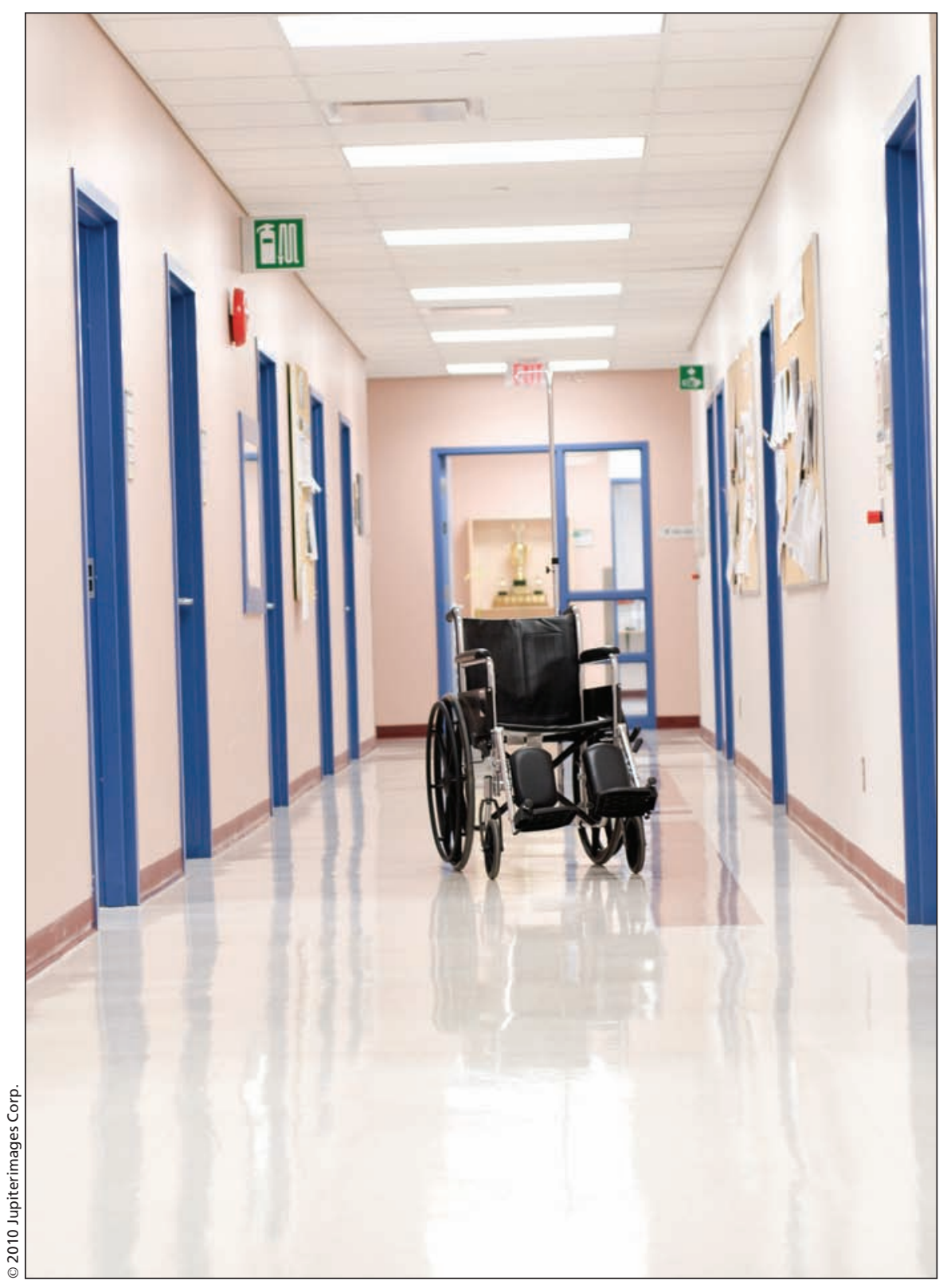

Manitoba's chief medical examiner says that Brian Sinclair would not have died had he received antibiotics and a new catheter.

At the centre of the controversy are claims by the health authority and other provincial officials that Sinclair never properly presented himself to the triage desk, and thus was never logged onto the waiting list to see a physician. That assertion prompted Dr. Thambirajah Balanchandra, Manitoba's chief medical examiner, to release a statement pointing out that there was video evidence showing that Sinclair lined up to see a triage nurse, but was taken out of 
the line by emergency department staff and put in the waiting area before he had a chance to formally request medical treatment.

To date, no one has explained why Sinclair was left in the waiting area for 34 hours without medical attention, despite efforts from security personnel to alert staff to his worsening condition. Balanchandra has said that antibiotics and a new catheter would have saved Sinclair's life.

Criminal prosecution of medical errors or negligence is virtually unheard of in Canada, although it is more common in the United States and the United Kingdom. "To describe the criminal prosecution of health care providers in the United States as a trend might be asking too much from the term when you compare the flurry of criminal cases to the blizzard of civil litigation providers face when they are accused of medical malpractice. None-the-less criminal prosecution for medical acts is on the rise," according to a study led by researchers at Yale University in New Haven, Connecticut (Internet J Law, Healthcare and Ethics 2007; 5[1]). "Between the time of the first such criminal case in 1809, Commonwealth of Massachusetts v. Thompson, and 1981, appellate courts heard approximately 15 similar cases. Over the next twenty years, approximately two dozen cases found their way into the lower courts."

Meanwhile, in the UK, a total of 28 known criminal prosecutions were initiated against 23 physicians between 1990 and 2003 (BMJ 2003; 327: 1118-

9). Another British study indicated that 85 physicians were charged with manslaughter between 1795 and 2005 (J R Soc Med. 2006; 99: 309-314.).

The Canadian Medical Protective Association, a national body which advises physicians on a wide range of legal issues including criminal proceedings, declined to comment on the Sinclair case or the broader issue of criminal proceedings for medical negligence.

Toronto lawyer Clayton Ruby, a member of the Sinclair family legal team, says criminal prosecution of medical professionals is rare because the standard necessary to prove criminal negligence causing death is higher than the civil standard used in malpractice lawsuits. "Criminal negligence requires not just a departure from competent care but a marked departure from that standard," Ruby says. "The criminal standard is much, much higher. As a result, you never see criminal charges laid against doctors or nurses."

But Ruby argues the Sinclair case is a good test for the criminal standard of negligence. "The guy was left for 34 hours and nobody apparently knew he was there. For someone to die from absolute inattention - that is a marked departure from the system. People make mistakes, but we're talking about someone who was literally left to die."

Sandi Mowat, president of the Manitoba Nurses Union, counters that there is absolutely no evidence to suggest that any person, or group of persons, working at the emergency department was deliberately responsible for Sinclair's death. While there was a profound breakdown in the system of logging in patients, "no one made a decision not to treat Brian Sinclair," she says.

Mowat is also concerned about the impact the case will have on recruitment and retention of emergency department nurses. Nurses who were on duty that night have been subjected to angry allegations and abusive commentary from patients, she says. "There are a lot of derogatory comments, like: 'Are you going to forget about me like you did Brian Sinclair?' That is not going to encourage a young nurse to work in an ER [emergency room], where it's not only physically demanding but also where there are many people who don't respect the work you do." - Dan Lett, Winnipeg, Man.

DOI:10.1503/cmaj.109-3721 